\title{
Hiperqueratosis Podal Felina asociada a Leishmaniasis. Reporte de Caso
}

\section{Feline foot hyperkeratosis associated with Leishmaniasis. Case Report}

DOI: $10.46932 / \mathrm{sfjdv2n2-082}$

Received in: March 1st, 2021

Accepted in: May 30th, 2021

\section{María José Tintel Astigarraga}

Doctora en Ciencias Veterinaria 2014 (UNA). Especialista en Diagnóstico Anatomohistopatológico Veterinario. 2018 (UNNE). Doctorando en Ciencias de la Salud, Fundación Oswaldo Cruz (Fiocruz). Investigadora asociada del Centro para el desarrollo de la Investigación Científica (CEDIC). Fundadora del Centro de Especialidades Veterinarias del Paraguay (CEV), responsable del Departamento de

Patología.

E-mail: tintelvet@gmail.com

\begin{abstract}
Leishmaniasis is a zoonotic parasitic disease that affects both humans and animals. Canines are considered the main reservoirs of the disease, while cats can present as secondary reservoirs, altering the epidemiological cycle of the disease. The present work describes the first case of feline foot hyperkeratosis in Asunción-Paraguay associated with leishmaniasis, determined by cytological diagnosis, with a favorable response to treatment and total resolution of the clinical symptoms.
\end{abstract}

Keywords: Leishmaniasis, zoonotic, cat, reservoir

\section{RESUMEN}

La leishmaniasis en una enfermedad parasitaria zoonótica que afecta tanto a humanos como animales. Los caninos son considerados los principales reservorios de la enfermedad, mientras que los gatos pueden presentarse como reservorios secundarios, alterando el ciclo epidemiológico de la enfermedad. El presente trabajo describe el primer caso de hiperqueratosis podal felina en Asunción- Paraguay asociada a leishmaniasis, determinado por diagnóstico citológico, con respuesta favorable al tratamiento y resolución total de la sintomatología clínica.

Palabras claves: Leishmaniasis, zoonosis, gato, reservorio.

\section{INTRODUCCIÓN}

La leishmaniasis es una enfermedad infecciosa parasitaria considerada zoonótica. A nivel mundial se encuentra entre las diez enfermedades tropicales desatendidas con más de 12 millones de personas infectadas. Esta infección es causada por un protozoo flagelado del género Leishmania spp, el cual es transmitida por la picadura de insectos dípteros de la familia Phlebotomidae (MSPBS, 2018; PAHO 2019)

Tradicionalmente la leishmaniasis afecta en gran medida a los caninos, considerada como uno de sus principales reservorios. Sin embargo, en los últimos años se han reportado a nivel mundial casos en felinos, específicamente en gatos, que en muchos casos no se realiza la búsqueda de Leishmania. 
La leishmaniasis felina es una enfermedad emergente, que se ha notificado tanto en regiones endémica (Pennisi- Persichetti, 2018) como no endémicas (Spada et al., 2020)y el gato puede cursar con infección crónica y desempeñar el papel de huésped adicional o secundario. Teniendo en cuenta los escasos reportes e inespecificidad de síntomas, el objetivo de este trabajo es reportar el primer caso de hiperqueratosis podal felina en Asunción asociada a leishmaniasis.

\section{METODOLOGÍA}

Se evalúa un felino mestizo, macho, 2 años de edad, $3.4 \mathrm{~kg}$ de peso vivo, sin antecedentes de padecer enfermedades. Se procedió a tomar muestras de la vena yugular para hemograma y perfiles bioquímicos. Además, aspirado aguja fina de médula ósea del manubrio del esternón para evaluación citológica medular y la confirmación del parásito PCR en tiempo real.

\section{RESULTADOS}

El felino examinado presentaba hiperqueratosis podal en los pulpejos de sus cuatro patas de aproximadamente 6 meses de evolución. También, se observó episodios de laceraciones y ulceraciones intermitentes y pérdida gradual de peso. Los resultados de laboratorio fueron:

\subsection{HEMATOLOGÍA}

Hemograma con ligera hiperproteinemia 8,69 g/dl (5,50 - 7,90), lo que refiere a perfil bioquímico leve incremento de GOT 63 U/L (10 - 55 U/L) como alteraciones relevantes.

\subsection{CITOLOGÍA MEDULAR}

Revela hiperplasia medular mieloide granulocítica con presencia de parásitos intracelulares ovalados a redondeados de 2 a $2,5 \mu \mathrm{m}$, con núcleo central y cinetoplasto en forma de barra lateral relacionados morfológicamente con amastigotes de Leishmania spp. (Fig. 1)

\subsection{PCR}

El resultado de la PCR en tiempo real confirmó la presencia de Leishmania infantum en la muestra de aspirado medular analizada.

\subsection{TRATAMIENTO}

Se suministró alopurinol a dosis de $10 \mathrm{mg} / \mathrm{kg}$ cada 12 h VO, al cabo de 30 días se obtuvo la mejoría clínica total del felino. (Fig. 2) 


\section{DISCUSIÓN}

El progreso de la patogenia de la leishmaniasis se ve influenciado en gran medida a la respuesta inmune que sea más estimulada, de tal manera se ha encontrado que en gatos la respuesta inmune que se da principalmente es de tipo celular dándole un grado más de resistencia de forma natural (Pennisi et al., 2015).

La diversidad de manifestaciones clínicas de la leishmaniasis felina (FeL), acompañada de las limitaciones diagnósticas, dificultan proporcionar un diagnóstico oportuno de la enfermedad. En felinos inmunocompetentes que no desarrollan síntomas clínicos relevantes podrían quedar como reservorios del parásito, por ende, es de vital importancia incluir como diagnóstico diferencial especialmente en zonas endémicas y la implementación de métodos repelentes para evitar la diseminación de la enfermedad. 


\section{REFERENCIAS BIBLIOGRÁFICAS}

Ministerio de Salud Pública y Bienestar Social (MSPBS). Manual de Diagnóstico y Tratamiento de las Leishmaniasis. -- Asunción: OPS/OMS. - 2018. ISBN: 978-99967-36-74-2

Organización Panamericana de la Salud; 2019. Disponible en: www.paho.org/leishmaniasis4. Organización Panamericana de la Salud; 2019. Disponible en: www.paho.org/leishmaniasis

Pennisi, M. Cardoso, L. Baneth, G. Bourdeau, P. Koutinas, A. Miró, G. Solano-Gallego, L. (2015). Actualización de LeishVet y recomendaciones sobre la leishmaniosis felina. Parásitos y vectores. 8(302). Pennisi MG, Persichetti MF. Leishmaniosis felina: ¿es el gato un perro pequeño? Veterinario Parasitol 2018; 251: 131-137.

Spada E, Perego R, Vitale F, Bruno F, Castelli G, Tarantola G, et al. Leishmania felina spp. Infección en una zona no endémica del norte de Italia. Animales (Basilea) 2020; 10(5): 817. 


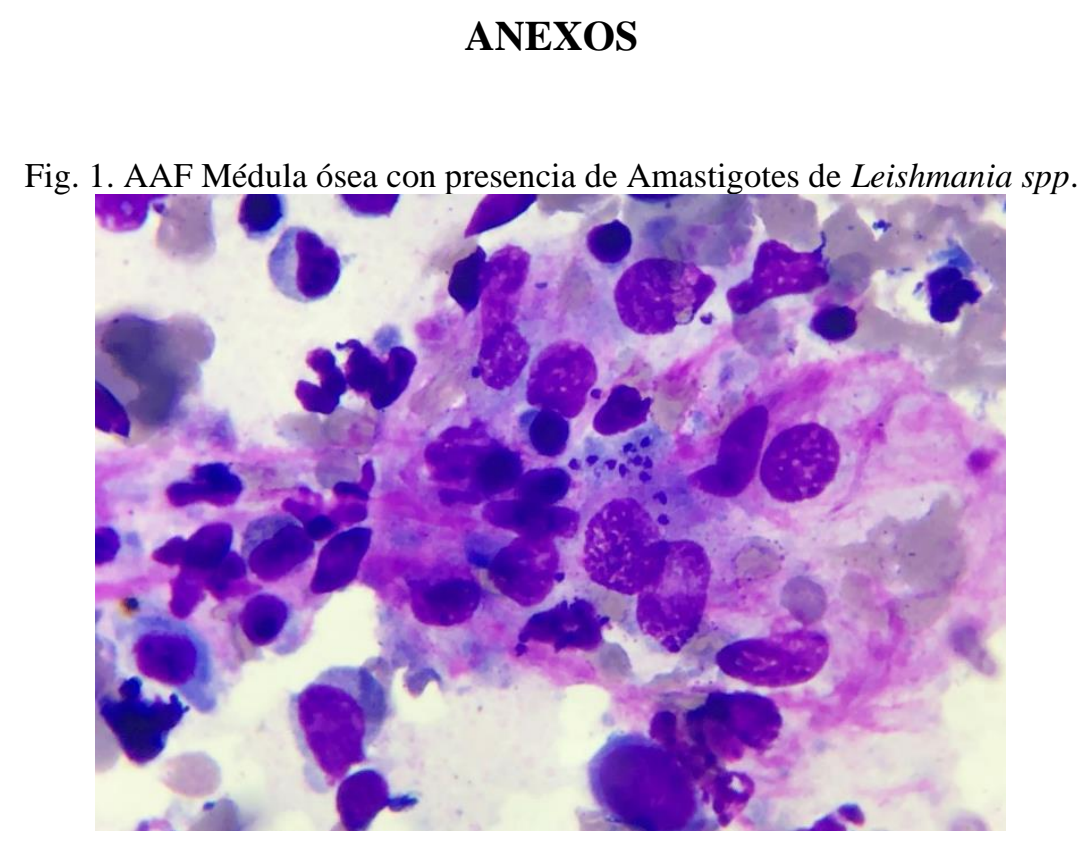

Fig. 2A Hiperqueratosis podal inicial.

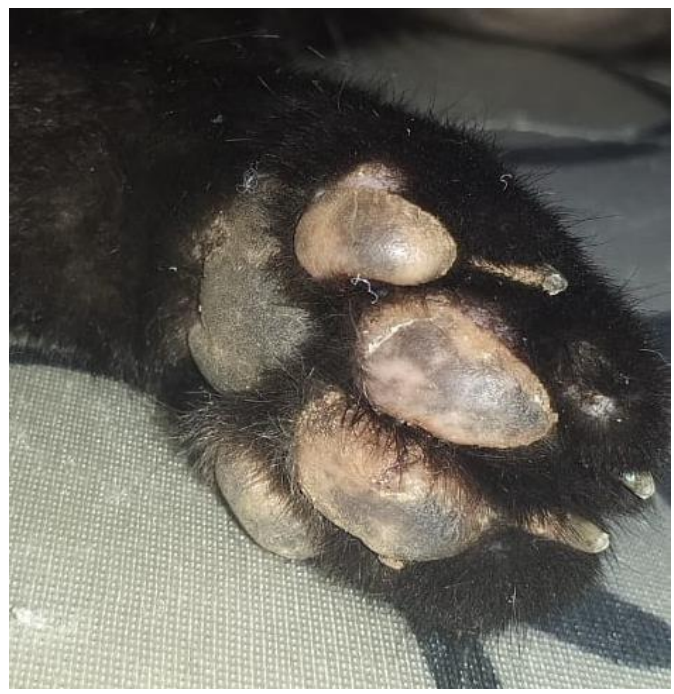

Fig. 2B Pulpejos con 10 días de tratamiento.

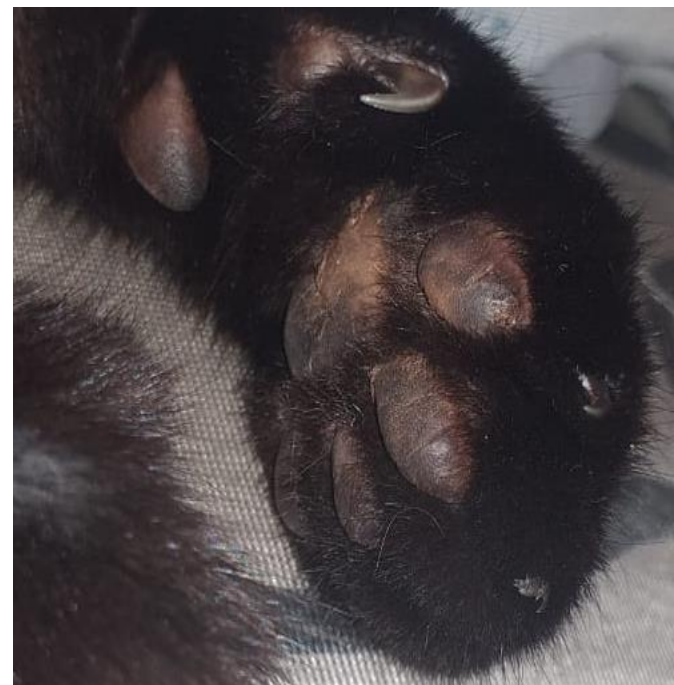

